American Journal of

Supply Chain Management

(AJSCM)

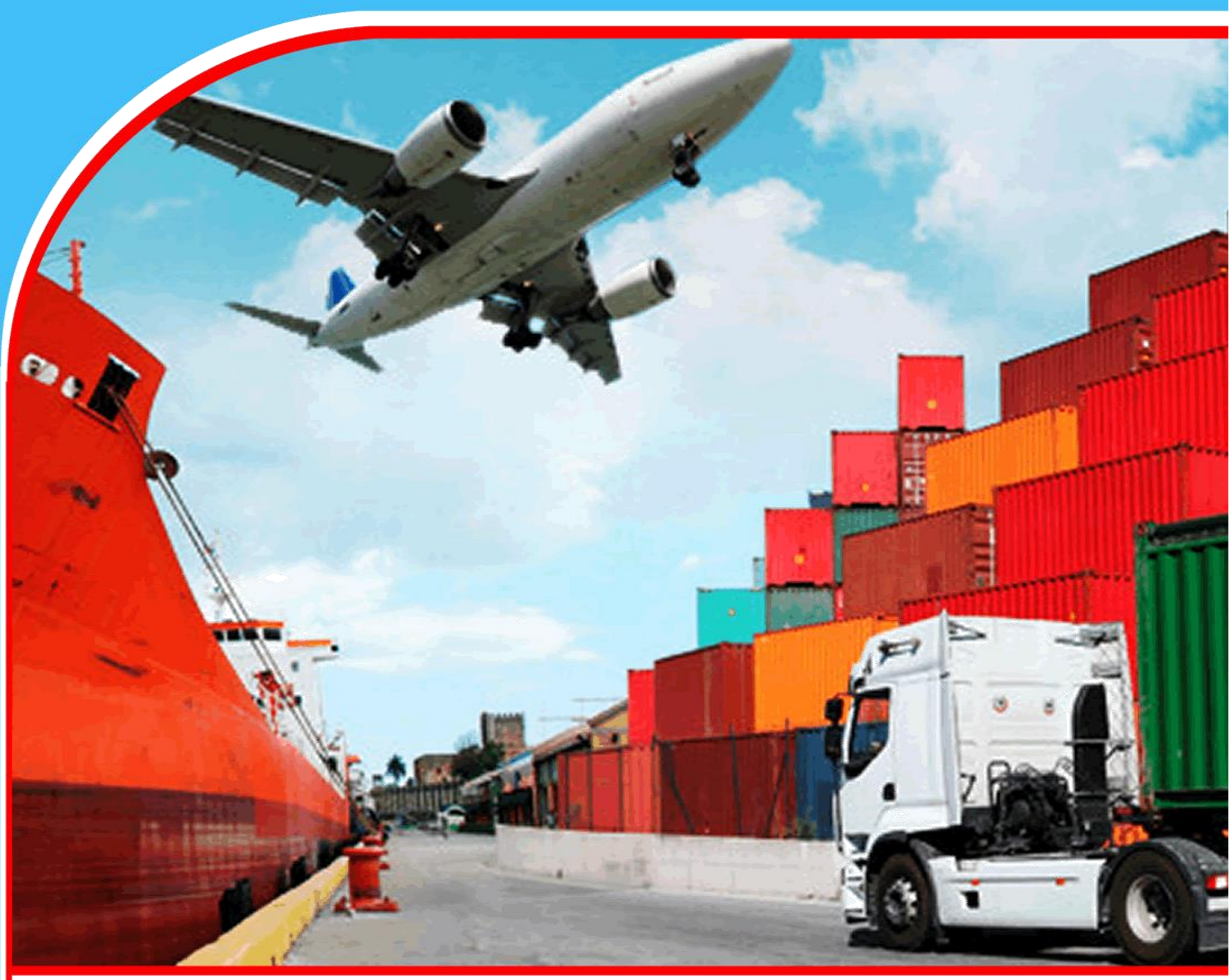

ROLE OF ORDER FULFILLMENT ON THE PERFORMANCE OF MANUFACTURING FIRMS IN KENYA

Salad Kikuyu Sarite, Prof. Mike Amuhaya Iravo and Dr. Noor Ismail

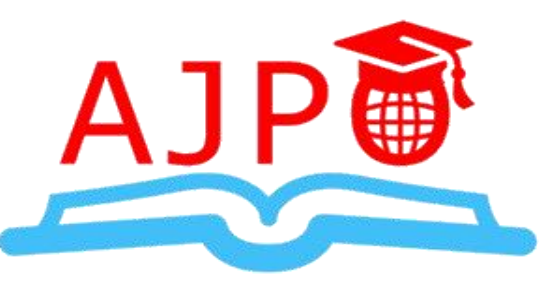




\title{
ROLE OF ORDER FULFILLMENT ON THE PERFORMANCE OF MANUFACTURING FIRMS IN KENYA
}

\author{
${ }^{1}$ Salad Kikuyu Sarite \\ Post Graduate Student, Jomo Kenyatta University of Agriculture and Technology \\ Corresponding Authors’ Email; saritesalad114@gmail.com \\ ${ }^{2}$ Prof. Mike Amuhaya Iravo \\ Lecturer, Jomo Kenyatta University of Agriculture and Technology \\ ${ }^{3}$ Dr. Noor Ismail \\ Senior lecturer, Jomo Kenyatta University of Agriculture and Technology
}

\begin{abstract}
Purpose: The main purpose of the study was determine role order fulfillment on performance of manufacturing firms in Kenya.

Methodology: A descriptive research design was used. The target population of the study were managers or equivalent from Six (6) departments that is Procurement, finance, legal, stores, human resource and quality control because they are directly concerned with supply chain. The study adopted the use of a questionnaire and a document analysis as the main research instrument. The study adopted both quantitative and qualitative approaches, implying that both descriptive statistics and inferential statistics were employed. Quantitative data collected from the document analysis was analyzed statistically using the Statistical Package for Social Scientist (SPSS version 22). The study tested the significance level of each independent variable against the dependent variable at $95 \%$ confidence level using ANOVA, Correlation and regression techniques.
\end{abstract}

Findings: The findings showed that order fulfillment has a positive and significant effect on firm performance, $0.723, \mathrm{p}<0.05$.

Unique contribution to theory, practice and policy: There is need to put in place review teams that constantly review the strategies with the view to improve them for increased effectiveness. Effective cost reduction mechanisms, combined with a well-structured organizational policy on procurement and supply chain management practices will eliminate the notion of having multiple suppliers to mitigate for unsatisfactory service.

Keywords: Order Fulfillment, Performance, Manufacturing, Firms, Supply Chain Management 


\subsection{INTRODUCTION}

Firm performance depends on whether or not a firm can create and commercialize knowledge in a timely and cost-efficient manner (Sampson, 2017). Performance of firms is of vital importance for stakeholders and economy at large. Successful implementation of supply chain collaboration has enhanced firm performance (Ramanathan, 2011). Supply Chain Collaboration emerged during early 20th Century in Japan (Nishiguchi, et al., 2014). Excessive demand for parts of goods after World War I urged many firms to utilize suppliers following the temporary increase in productions. In 1960s and '70s supply chain collaboration were characterized by an adversarial, arm's -length approach suiting price oriented buying. At the beginning of the ' 90 s, supply chain collaboration required an even greater degree of interaction due to the added need for product innovation and cooperation in technological developments, and this high level of interaction is termed partnership (Lamming, 2013).

Firms compete in head-to-head battles for market share and position with other organizations in their competitive sets. Here suppliers are often treated in an adversarial manner by buyers, as the relationship between buyers and suppliers are viewed in a winlose situation (Shapiro, 2012). It is imperative, therefore for firms to appreciate that supply chain relationships are not simple to cultivate and maintain collaborative efforts. The supply chain collaboration should be for a strategic subset of suppliers and customers of the supply chain. These subsets of suppliers are firms that provide strategic products, or services, or who purchase large quantities of finished goods. This has brought about the concept of supplier positioning where suppliers are classified in different categories based on the product value and risks (Spekman, 2008).

Today, manufacturing firms must satisfy customers' needs for quick and on-time delivery of quality products at lower prices, even in unpredictable economic crises and amidst natural disasters. Firms in a supply chain collaborate with their partners in the chain to cope with such challenges in a more efficient way than they could do so individually. Thus, order fulfillment in supply chain management (SCM) has been gaining in importance for firms to survive the global competition. Managing order fulfillment in supply chain aims at challenging constantly the corporate strategy by setting a new environment where cost savings must be done whenever an opportunity appears (Machikita \& Ueki, 2012).

International trade is growing rapidly for both developing and developed countries (World Bank group, 2015) and economies of countries such as the USA and china have become increasingly intertwined (Akech, 2015). Collaboration between firms, personal relationships lie at the core of interfirm relationships (Pradabwong et al., 2017). Supply chain boundary spanners, personnel who operate across and interact with channel members outside the firm (customers, suppliers and third parties) are the main conduct through which such buyer and supplier relationship thrive (Cao \& Zhang, 2011). 
Foster (2015) stated that there are a number of benefits that firms derive from successfully managing order fulfillment SRM. This include: reduced costs and increased efficiency beyond traditional sourcing and category management efforts by setting up long-term relationships and establishing communication processes; managing supplier risk and compliance by strengthening global transparency and visibility on key relationships through policies and processes, metrics and tools; driving supplier performance in a transparent and sustainable manner with strategic suppliers and collaboration partners; enabling continuous improvement of operations through long-term relationships with suppliers, allowing for the creation of a more effective and efficient supply chain; fostering business development and innovation by jointly identifying and implementing innovation and new market opportunities, sharing vision and strategy through joint planning early on to improve go-to market time (Duffy, 2014).

While some studies support a direct relationship between supply chain collaboration and performance, others find no significance. Setting and type of performance analyzed makes an impact; however, if some collaboration cannot report a direct effect with performance why would firms enter into these arrangements. This is best answered by the indirect effects collaboration can have on performance through synergies shared and expanded on by partners as well as the relational benefits of successful collaborations. While quantifying the true cost of collaborations and judging the value they provide to firms remains a challenge, one cannot argue the supply chain collaborations can impact performance.

Besides, only a few studies have been carried out in Kenya on supply chain collaboration including Barasa et al. (2015) on the impact of supply chain 63 collaboration practice on the performance of steel manufacturing companies in Kenya; Bolo and Wainaina (2011) in a study on An Empirical Investigation of Supply Chain Management Best Practices in Large Private Manufacturing Firms in Kenya; Kingoo (2013) in a study on Supply Chain Governance and Organizational Performance among Parastatals in Kenya. However, there is no study in Kenya carried out on effect of supply chain collaboration on performance of manufacturing firms in Kenya. This is an indication that little attention has been paid to supply chain collaboration and performance of model in Kenya. This study consequently filled in on this existing knowledge gap and added value to existing literature by providing experiential supply chain collaboration and performance of in Kenya can adopt so as to gain sustainable collaborative advantage. The study relied on descriptive research survey design where the respondents were asked to describe viewpoints on the item in the instrument as at the time of the study. However, it is evident that some success factors of supply chain collaboration are strategic and dynamic in nature. Hence, a cross-sectional study design would be more ideal as it could provide a deeper insight and perspective of the effect of supply chain collaboration on the performance of in Kenya.

Ho1: There is no significant influence of Order fulfillment on performance of manufacturing firms in Kenya 


\subsection{EMPIRICAL REVIEW}

\subsection{Theoretical Review}

\subsubsection{Theory of Constraints (TOC)}

The theory of constraints (TOC) has been widely known as a management philosophy coined by Goldratt (1990) that aims to initiate and implement breakthrough improvement through focusing on a constraint that prevents a system from achieving a higher level of performance. The TOC paradigm essentially states that every firm must have at least one constraint. Goldratt and Cox (1992) define a constraint as any element or factor that limits the system from doing more of what it was designed to accomplish (i.e., achieving its goal). The owner of a system is assumed to establish its goal. The fundamental goal of most business entities is to make money now and in the future. Other stakeholders may develop necessary conditions that must be met to allow the system to continue operating. The TOC thus encourages managers to identify what is preventing them from moving towards their goals - as well as necessary conditions - and find solutions to overcome this limitation.

The TOC comprises a set of three separate but interrelated areas - namely, logistics, performance measurement, and logical thinking (Cox \& Spencer, 1998; Simatupang et al., 1997). The TOC applications to logistics include the drum-buffer-rope scheduling method, buffer management, and the VAT analysis. Measurements are required to determine whether or not the system is accomplishing its goal of making money. Performance measurement includes operating measures (i.e., throughput, inventory, operating expenses) and local performance measures (i.e., throughput-dollar-days and inventory-dollar-days). Logical thinking comprises the five-step-focusing process and the thinking processes.

The TOC solutions initially attempted to resolve core problems in production systems using methods such as the drum-buffer-rope scheduling, constraint-focused performance measurement, and buffer management (Goldratt \& Cox, 1992). Further development of the TOC incorporates solutions for marketing and sales (Goldratt, 1994), project management (Goldratt, 1997), and supply chain management (Goldratt et al., 2000). Blackstone (2001) provides an exhaustive review of the latest developments of the TOC applications. Over the last decade the development of the TOC and accounts of its application have burgeoned with the publication of a considerable number of articles, proceedings, and books based on the TOC approach (Mabin \& Balderstone, 1999). Rahman (1998) reviews the TOC approach on manufacturing firms. Siha (1999) applies the TOC approach to addressing problems in different types of service organisations. Beyond business firms, Klein and Debruine (1995) and Dettmer (1998) used the TOC thinking processes to identify core problems in public policies. Womack and Flowers (1999) applied the TOC approach to the healthcare system to improve its performance. 
Literature on TOC supply chain solutions deals mainly with managing the supply chain from a single enterprise perspective (Cox and Spencer, 1998; Jackson and Low, 1993). Umble et al. (2001), for instance, described how a manufacturing firm applied the TOC approach to direct the implementation of enterprise resource planning (ERP). Gupta (1997) also recognizes that the TOC approach can be used to guide a single firm to concentrate on exploiting resources based on different logistics cost along the supply chain.

Little attention has been given, within the literature, to the application of the TOC concepts to the management of supply chains where collaboration must be fostered between independent firms. Covington (1996) applied the TOC thinking process to identify problems in the apparel supply chain and describes the bringing together of managers from different firms to cooperate in improving the overall supply chain profit. Stein (1997) proposed a conceptual model of locating the time buffer at different positions of participating members to protect actual sales from demand and supply uncertainty. Goldratt et al. (2000) conceptualized performance measures to maintain trust amongst the participating members.

Nowadays, the competition is not among companies but among the SCs, which belong to (Srinivasan et al., 2005). In that scenario, although the main goal of the SCM is to reach a solution with optimized profit for all SC's partners, there is often a great disparity between potential benefits and the practice (Simatupang et al., 2004). This situation occurs because there are several difficulties regarding SC which need to be solved by an efficient SCM. Some of these difficulties are: very long lead times, large number of unfulfilled orders and/or they are executed with much extra effort(overtimes), high level of unnecessary inventories and/or lack of relevant inventories, wrong materials orders, large number of emergency orders and expedition levels, high levels of devolution, lack of key customers engagement, frequent changes and/or absence of control related to priority orders, which implies on schedule conflicts of the resources, among many others (Goldratt et al., 2000).Despite the noticeable worldwide performance improvement of the SC, the main problem observed is that the SC's partners have not been achieving better results related to profitability and efficiency, because most of the time, each one of them just considers their local constraints (own problems), when they should be considering all global constraints related to SC as a whole. In fact, the design and analysis of the SC as a whole is critical to develop an efficient SCM (Wang et al., 2004). In this study, it is proposed to use the Theory of Constraints (TOC) to help companies in a make-to-stock SC through order fulfillment. Thus, the theory supports the objective of effect of order fulfillment on performance of manufacturing firms.

\subsection{Literature review}

Order fulfillment involves generating, filling, delivering and servicing customer orders. To accomplish these tasks, management must design a network and a fulfillment process that permits the firm to meet customer requests while maximizing profitability. At the operational level, the order fulfillment process focuses on transactions, and is largely executed within the 
logistics function, but at the strategic level, management should focus on making critical decisions about the process that influence the performance of the firm, its customers and its suppliers. This requires integration of all the key functions and is enhanced through collaboration and coordination with key suppliers and customers.

Order fulfillment cycle (OFC) comprises the process in receiving, processing and delivering a customer order. It refers to all the steps companies must take from the moment they receive an order until the goods land in customers' hands. There are many types of order fulfillment options such as Engineer-to-Order where the product is completely build and designed to customer specifications, or Assemble-to-Order where the product is built to customer specifications from an inventory of existing materials, and finally to Make-to-Stock (MTS) where the product is built against a sales forecast, and sold to the customer from an inventory of finished goods. If the product is in digital form, the option might even be Digital Copy where products are digital assets and copies are created on-demand, downloaded by the customer and saved on their storage devices (Orrigo, 2015).

Based on Meller (2015) Order fulfillment cycle time (OFCT) can be defined as the amount of time from customer leaving the sales order to the customer receiving the product he ordered. It is an important factor for customers as it represents the total "time of waiting". The order fulfillment cycle consists of three different components each requiring different amount of time. These components are: Order Reception Window: The time window in which orders are received be- tween two consecutive order cut-off times. For example, the order cut-off time could be at 12:00 am each weekday. If an order is received before $12 \mathrm{am}$, the order processing will start right after $12 \mathrm{am}$. If an order is received after $12 \mathrm{am}$, the order is moved to the next day and order processing will start the next day after 12 am. Order Processing Window: The time it takes to process an order in the ware- house or distribution centre. This process includes planning, picking, and packing, labeling, and loading it on a truck for shipment to the customer. The order must be processed so that it will be completed by the transportation cut-off time. If the order is not completed by the transportation cut-off time, the truck will not leave in scheduled time which means that the order delivery will be late, or that the truck might leave without the order, which also means that the order delivery will be late. Transportation Window: The time it takes to transport the order to the customer once it has been shipped from the warehouse or distribution centre.

The order fulfillment process affects the financial performance of the firm. For instance, within the order fulfillment process the team will make decisions about how orders will be filled for each customer segment, assuring that these activities, and their costs, are aligned with customer profitability. An optimized network minimizes total delivered costs, including sourcing costs, while meeting service level requirements. A streamlined process reduces the order-to-cash cycle which frees up capital, and reduces the delivery lead-time which allows for reduced inventory levels. The effectiveness of the process can also affect the financial performance of suppliers and customers. The focal firm's ability to deliver to the customer the right quantity at the right time prevents manufacturing disruptions, or in the case that the customer is a retailer, prevents empty shelves 
Refers to a system of interrelated components working together in order to collect, process, store and disseminate information to support decision-making, control and analysis in an organization (Landon and Landon 2005). Information technology and in particular the Internet have played a fundamental role in helping firms reach the goals of supply chain Collaboration. The Internet can change the role and type of relationships between the various players, creating new value networks and developing new business model (Muffatto \& Payaro, 2004). These systems must fit within the organizational requirements of the supply chain/network members, or else the overall acceptance may not be adequate for the system's use (Volkoff et al., 1999).

Information systems in particular have contributed to the establishing of Supply chain management systems which link suppliers to the buyer organization promoting supplier intimacy (Landon and Landon, 2005). It has also led to the application internet in the application of Electronic data exchange systems. The Internet has given firms even greater tools for tightly orchestrating relationships across the entire supply chain and creating strategic partnerships and operational linkages with a dynamic web of large and small firms spanning all continents (Hamner \& Qazi, 2009). Internet-enabled shared information helps break down organizational policies and functional fences, helping supply chain alliance members develop a common understanding of the competitive environment (Boyson et al., 1999).

Information Systems researchers have mainly focused on the impact of IT in reducing coordination costs. This includes the cost of exchanging information and incorporating that information into decision processes as well as the cost incurred by the firm due to delays in the communication channel (Clemons et al., 2013). Within the context of transaction cost theory, this is a major component of transaction costs. However, the other major component, transaction risk, includes the risk of opportunistic behavior as well as the risk due to information asymmetry among the parties. One party could avoid responsibilities due to the inability of the other party to monitor Hanley (2002). In addition, as indicated earlier, one party could take advantage of the relation-specific investments of the other. In addition to coordination cost, IT can reduce transaction risk by providing effective monitoring capabilities (Clemons et al., 2013).

\subsection{METHODOLOGY}

The study employed both cross-sectional research design and explanatory research design using Positivism approach. The target population of this study were 213 registered manufacturing firms in Nairobi County (KAM, 2013). The study used a confidence level of $95 \%$ hence a margin of error of 0.05 . The Slovin formula is used where the researcher has no idea of the population behavior. It was developed by Slovin in 1960. The sample size was 138 . The study adopted the use of a questionnaire and a document analysis as the main research instrument. Document analysis was carried out through desk research and involved a review of literature such as reports and books. The Cronbach's alpha could also be used to assess the reliability of an instrument. This component accounts for $61.163 \%$ of the variance in order fulfillment. The next 4 items (We deliver orders on time to our customers, we ensure that all orders are efficiently and effectively delivered to customers, when we promise to fulfill orders we do it and we show sincere interest in solving customers problems related to order 
fulfillment) regarding order fulfillment loaded heavily onto the second component and can be summed up to relate to service quality and customer focus in supply chain process and accounts for $20.316 \%$ of the variation in order fulfillment and cumulatively, both components account for $81.479 \%$ of the variation in order fulfillment. Sampling adequacy was tested using the Kaiser- Meyer- Olkin Measure (KMO measure) of sampling adequacy. As evidenced in Table 4.1 KMO was greater than $0.5(0.723)$, and Bartlett's Test was significant, $\chi 2(21)=$ 679.751, p-value $<0.000$

\section{Table 1: Sampling Adequacy}

\begin{tabular}{|l|l|l|}
\hline & $\begin{array}{l}\text { loading } \\
\text { S }\end{array}$ & Mean \\
\hline We keeps statement related to orders accurately & 0.652 & 4.15 \\
\hline $\begin{array}{l}\text { We promptly response to customer orders regardless of the order } \\
\text { size }\end{array}$ & 0.953 & 3.2 \\
\hline We frequently response to customer orders & 0.911 & 2.76 \\
\hline We deliver orders on time to our customers & 0.856 & 3.21 \\
\hline $\begin{array}{l}\text { We ensure that all orders are efficiently and effectively delivered to } \\
\text { customers }\end{array}$ & 0.95 & 3.5 \\
\hline When we promise to fulfil orders we do it & 0.705 & 3.91 \\
\hline $\begin{array}{l}\text { We show sincere interest in solving customers problems related to } \\
\text { order fulfilment }\end{array}$ & 0.683 & 3.23 \\
\hline Total Variance Explained & \multicolumn{2}{|l|}{} \\
\hline Eigenvalues & 4.281 & \\
\hline$\%$ of Variance & 61.163 & \\
\hline Cumulative \% & 81.479 & \\
\hline KMO and Bartlett's Test & 0.723 & \\
\hline Kaiser-Meyer-Olkin Measure of Sampling Adequacy. & 679.751 & \\
\hline Bartlett's Test of Sphericity, $\chi 2$ & 21 & \\
\hline df & 0 & \\
\hline Sig. & 0.94 & \\
\hline Cronbach's Alpha & & \\
\hline
\end{tabular}

\subsection{Data Analysis and Presentation}

The study adopted descriptive research design. Descriptive and inferential were used. The correlation analysis was used to give correlation coefficients between the independent variable and dependent variable. A regression model was used to test the relationship between older fulfillment in supply chain collaboration as a linear function of the independent variables. The $\beta \mathrm{s}$ in the equation represent the estimated parameters which represents the Beta coefficients of the respective independent variables as indicated below.

$\mathrm{y}=\beta_{0}+\mathrm{C}+\beta_{1 \mathrm{a}} \mathrm{x}_{1}+\varepsilon \ldots$ Where:

$\mathrm{Y}=$ performance of manufacturing firms

$\beta 0=$ constant Term 
$\beta_{1}=$ Beta coefficients

$\mathrm{X}_{1}=$ Order fulfillment

$\mathrm{e}=$ Error term

\subsection{FINDINGS}

The mean response was $3.23(\mathrm{std}$. dev. $=1.046)$ which indicated overall neutrality with the statement. This means that there are gaps in the ability of the firm to respond to customer orders and this confirms the challenge in terms of timely meeting of customer orders. The overall mean response was 3.423 (std. dev. $=0.800$ ) that indicated a general neutrality with the aspect of order fulfillment in the manufacturing firms. The main gaps identified were in terms of timely delivery of orders to customers, ability to meet orders despite the size of the order, ability to respond to customer problems and documentation. The overall mean response was $3.58(\mathrm{std}$. dev. $=0.541)$ that indicated overall agreement with the statements regarding firm performance. Furthermore, the relationship between order fulfillment and firm performance was found to be positive and significant, $\rho=0.723$, $p$-value $=0.000$ which shows that there is $72.3 \%$ probability that the firm's performance will increase with increased order fulfillment and components that define order fulfillment.

\section{Table 4.1: Correlations}

\begin{tabular}{lrrlll}
\hline & mean & STD & & $\begin{array}{l}\text { Firm } \\
\text { performance }\end{array}$ & \multicolumn{1}{l}{$\begin{array}{l}\text { Order } \\
\text { fulfilment }\end{array}$} \\
\hline Firm performance & 3.58 & 0.541 & & 1 & 1 \\
Order fulfilment & 3.423 & 0.8 & $0.723^{* *}$ & & 1 \\
\hline
\end{tabular}

** Correlation is significant at the 0.01 level (2-tailed).

The objective of this study was to examine the role order fulfillment on performance of manufacturing firms in Kenya. As such, this study aimed to test the hypothesis stating that there is no significant influence of Order fulfillment on performance of manufacturing firms in Kenya. The findings regarding this were presented in Table 3 
Table 4.2: Effect of order fulfillment on firm performance

\begin{tabular}{|c|c|c|c|c|c|}
\hline & $\begin{array}{r}\text { Unst: } \\
\text { Co } \\
\end{array}$ & $\begin{array}{l}\text { ardized } \\
\text { cients } \\
\end{array}$ & $\begin{array}{c}\text { Standardized } \\
\text { Coefficients }\end{array}$ & & \\
\hline (Constant) & $\begin{array}{c}\mathbf{B} \\
1.666\end{array}$ & $\begin{array}{c}\text { Std. Error } \\
0.182\end{array}$ & Beta & $\begin{array}{c}\mathbf{t} \\
9.17\end{array}$ & $\begin{array}{l}\text { Sig. } \\
0.00 \\
0\end{array}$ \\
\hline $\begin{array}{l}\text { Order } \\
\text { fulfillment }\end{array}$ & 0.585 & 0.054 & 0.723 & $\begin{array}{c}10.88 \\
2\end{array}$ & $\begin{array}{c}0.00 \\
0\end{array}$ \\
\hline Summary Statistics & 0723 a & & & & \\
\hline R Square & 0.523 & & & & \\
\hline $\begin{array}{l}\text { Adjusted } \quad \mathrm{R} \\
\text { Square }\end{array}$ & 0.519 & & & & \\
\hline $\begin{array}{l}\text { ANOVA } \quad \text { (F- } \\
\text { stat) }\end{array}$ & 118.427 & & & & \\
\hline $\begin{array}{l}\text { ANOVA } \quad(p \\
\text { value) } \\
\text { a Dependent Variab }\end{array}$ & $\begin{array}{l}0.000 \mathrm{~b} \\
\text { le: firm } \mathrm{p}\end{array}$ & rmance & & & \\
\hline
\end{tabular}

The findings in Table 4.2 revealed that order fulfillment accounts for $52.3 \%$ of the variation in firm performance $(R$-square $=0.523$, adj. $R$-square $=0.519)$. Furthermore, the variation accounted for the model on firm performance is significant, $F=118$. 427, $p<0.05$. The findings on the effect of order fulfillment revealed that order fulfillment has a positive and significant effect on firm performance, $0.723, p<0.05$. This means that with each unit increase in order fulfillment, there is 0.723 unit increase in firm performance. These findings imply that the hypothesis stating that there is no significant influence of order fulfillment on performance of manufacturing firms in Kenya is not accepted and the conclusion is that order fulfillment has a positive and significant effect on performance of manufacturing firms in Kenya. These findings highlight the key aspects of the stakeholder theory in which Theyel (2010) argues that firms that seek to develop and implement a proactive strategic environmental commitment are considered to be more aware of stakeholder needs than those that are only concerned with meeting minimum environmental regulation requirements.

Landon and Landon (2005) also refer to a system of interrelated components working together in order to collect, process, store and disseminate information to support decisionmaking, control and analysis in an organization (Information technology and in particular the Internet have played a fundamental role in helping firms reach the goals of supply chain Collaboration. The Internet can change the role and type of relationships between the various players, creating new value networks and developing new business model (Muffatto \& Payaro, 2004). These systems must fit within the organizational requirements of the supply chain/network members, or else the overall acceptance may not be adequate for the system's use (Volkoff et al., 2009). This means that while the end-goal is to ensure that obligations are met especially in the supply chain process, there is need to keep in mind 
of how the obligations are going to be met effectively and with minimal wastage of essential resources. Information Systems researchers have mainly focused on the impact of IT in reducing coordination costs. This includes the cost of exchanging information and incorporating that information into decision processes as well as the cost incurred by the firm due to delays in the communication channel (Clemons et al., 2013).

Information systems in particular have contributed to the establishing of supply chain management systems which link suppliers to the buyer organization promoting supplier intimacy (Landon and Landon, 2005). It has also led to the application internet in the application of Electronic data exchange systems. The Internet has given firms even greater tools for tightly orchestrating relationships across the entire supply chain and creating strategic partnerships and operational linkages with a dynamic web of large and small firms spanning all continents Hamner and Qazi, (2009). Internet-enabled shared information helps break down organizational policies and functional fences, helping supply chain alliance members develop a common understanding of the competitive environment (Boyson et al., 1999).

\subsection{CONCLUSIONS AND RECOMMENDATIONS}

\subsection{Conclusion}

The findings showed that order fulfillment has a positive and significant effect on firm performance. This means that the hypothesis stating that there is no significant influence of order fulfillment on performance of manufacturing firms in Kenya is rejected. However, in majority of the manufacturing firms, there were challenges in terms of the full implementation of practices and policies that would enhance order fulfillment in supply chain management. These findings highlight a gap in the supply chain management processes where there might exist policies and procedures regarding order fulfillment but the full benefits are not realized because of incomplete implementation of such procedures or the absence of procedural alignment between the firms and their customers. In addition, there are obvious gaps in terms of efficient and effective delivery of orders to the customers given the gaps in terms of timely delivery of orders.

Although there might be a genuine concern and intention to solve customers' problems related to order fulfillment there were challenges in doing so, for instance, policy inherent gaps and company culture that might hinder the process of addressing customers' concerns. However, there is a gap in documentation which might impact negatively on order fulfillment to their customers. This gap entails accuracy and quality of documentation. There are also challenges in the ability to respond to customer orders regardless of the order size and gaps in the ability of the firm to respond to customer orders and this confirms the challenge in terms of timely meeting of customer orders. The main gaps identified were in terms of timely delivery of orders to customers, ability to meet orders despite the size of the order, ability to respond to customer problems and documentation. 


\subsection{Recommendations}

The findings have revealed challenges in the full implementation of practices and policies that would enhance order fulfillment in supply chain management. In addition, there are obvious gaps in terms of efficient and effective delivery of orders to the customers given the gaps in terms of timely delivery of orders, address of customers' problems, documentation, ability to deliver orders and timely delivery of the orders. As a result, manufacturing firms need to put in motion mechanisms of ensuring that the policies developed for supply chain management are implemented fully. This can be done by ensuring that all stakeholders are involved in the development of the policies and that the policies address the concerns of all the concerned parties. Furthermore, the firms need to structure capacity building mechanisms to inform the members of the importance of the policies in enhancing procurement and supply chain management practices.

While there are firm-inherent factors that determine the direction of supply chain collaboration; there are factors that are inherent from the suppliers' side in terms of policies and operational procedures that might have an influence on the firms' practices in supply chain management. Thus, there is need to have a deeper look into the role of the suppliers, in terms of supply practices and policies, so as to get an overview of the challenges with view of addressing them from all angles.

\section{REFERENCES}

Adeniji, A. A. (2011). Cost Accounting: A Managerial Approach (5st ed.). EL-TODA Ventures Ltd

Akech, J. M. M. (2015). Development partners and governance of public procurement in Kenya: enhancing democracy in the administration of aid, Vol. 20, pp. 1-63.

Barasa, P., W., Simiyu, G., W., \& Iravo M., A. (2015). The impact of supply chain collaboration practice on the performance of steel manufacturing companies in Kenya, European Journal of Logistics Purchasing and Supply Chain Management, 3(2), 28-39,

Bolo, A., Z., \& Wainana, G. (2011). An Empirical Investigation of Supply Chain Management Best Practices in Large Private Manufacturing Firms in Kenya. Prime Journal of Business Administration and Management, 1(2), 2-3.

Boyson, S., Corsi, T., Dresner, M., \& Rabinovich, E. (1999). Managing effective 3PL relationships: what does it take? Journal of Business Logistics, 21(1), 73-100.

Cao, M., \& Zhang, Q. (2011). Supply chain collaboration: Impact on collaborative advantage and firm performance. Journal of Operations Management, 29(2011), $163-180$. 
Clemons, Eric K., Sashidhar P. Reddi, and Michael C. Row. 2013. The impact of information technology on the organization of economic activity: the "move to the middle" hypothesis. Journal of Management Information Systems 10 (2): 9-35

Goldratt, E. M. (1990b). The Haystack Syndrome, North River Press, Great Barrington, MA, pp. 144-55.

Goldratt, E.M. and Cox, J. (1992), The Goal: A Process of Ongoing Improvement, North River Press, Croton-on-Hudson, NY

Goldratt, E.M. (1990a), Theory of Constraints, North River Press, Croton-on-Hudson, NY.

Goldratt, E.M. (1994), It's Not Luck, North River Press, Great Barrington, MA.

Goldratt, E.M. (1997), Critical Chain, North River Press, Great Barrington, MA

Hamner, M. and Qazi, R. (2009), "Expanding the technology acceptance model to examine personal computing technology utilization in government agencies in developing countries", Government Information Quarterly, Vol. 26, pp. 128-36

Kingoo, E., M. (2013). Supply Chain Governance and Organizational Performance among Parastatals in Kenya .Unpublished MBA project, Nairobi: University of Nairobi

Lamming, J. (2013), "Are individual differences germane to the acceptance of new information technologies?” Decision Sciences, Vol. 30 No. 2, pp. 361-91.

Mabin, V.J. and Balderstone, S.J. (1999), The World of the Theory of Constraints, Lucie Press, Boca Raton, FL.

Machikita, T. and Y. Ueki. 2011a. Innovation in linked and non-linked firms: effects of variety of linkages in East Asia. International Journal of Institutions and Economies 3(1): 77-102.

Machikita, T. and Y. Ueki. 2011b. The Impacts of face-to-face and frequent interactions on innovation: Upstream downstream relations. International Journal of Institutions and Economies 3(3): 519-548

Muffatto, M., \& Payaro, A. (2004). Integration of web-based procurement and fulfillment: A comparison of case studies. International Journal of Information Management, 24, 295-311

Spekman, P (2008), "Business-to-business procurement performance: success factors and challenges to implementation", Supply Chain Management: An International Journal, Vol. 12 No. 2, pp. 104-15. 
Spekman, R.E., Kamauff, J.W. and Myhr, N. (1988), "An empirical investigation into supply chain management: a perspective on partnerships", International Journal of Physical Distribution \& Logistics Management, Vol. 28 No. 8, pp. 630-50. Applying the theory of constraints to supply chain collaboration (PDF Download Available).

Umble, E.J., Haft, R.R., Umble, M.M. (2003). Enterprise resource planning: Implementation procedures and critical success factors. European Journal of Operational Research 146, 241-257 